\title{
Reflections of the incoming president of the CAG
}

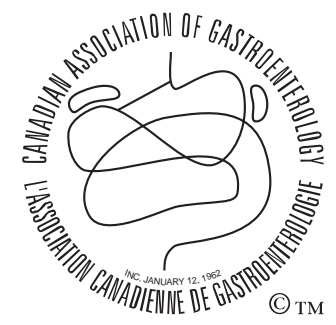

En français voir page 205

\author{
Philip M Sherman MD FRCPC \\ President, the Canadian Association of Gastroenterology
}

$\mathrm{I}$

$\mathrm{t}$ is with both great anticipation and some trepidation Ithat I take on the duties and responsibilities as the 39th president of the Canadian Association of Gastroenterology (CAG). The past few years have been highlighted by the development of a Canadian Digestive Disease Week (CDDW), the creation of a fully staffed National Office headed by a superb executive director, Paul Sinclair, and the formation of a sister funding organization, the Canadian Digestive Health Foundation. My immediate predecessors, Richard Fedorak and John Wallace, deserve our thanks for leading the implementation of these initiatives. I look forward to continuing to work with the past presidents of the CAG in planning for the future.

During these times of change and challenge, we cannot, however, rest on our laurels. We will update a strategic plan developed some 10 years ago in order to set an agenda for how the CAG will work to fulfill your needs over the next decade. Our organization serves a diverse constituency, and we must continue to work to serve the goals and aspirations of all of our members. It is my intention to take advantage of the immense talent and great energy of our members as a lobbying force. We must be proactive in our interactions with federal and provincial governments, disease-related agencies and partners in industry to acquire the additional resources that are desperately needed if we are to optimize the digestive health of Canadians.

Listed below are the current members of the CAG Executive, along with telephone numbers and e-mail addresses. Please do not hesitate to contact any one of us with comments, concerns and feedback.
President

Phil Sherman

Telephone: 416-813-7734

E-mail: President@cag-acg.org

President-Elect

Des Leddin

Telephone 902-473-7833

E-mail: PresidentElect@ $@_{\text {cag-acg.org }}$

Past-President

John Wallace

Telephone 403-220-4539

E-mail: PastPresident@cag-acg.org

Secretary

Mary Perdue

Telephone 905-525-9140

E-mail: Secretary@cag-acg.org

Finance

David Morgan

Telephone 905-574-7221

E-mail: Finance@cag-acg.org

\section{Treasurer}

Alan Cockeram

Telephone 506-634-7742

E-mail: Treasurer@cag-acg.org

Planning is already underway for CDDW 2003, which will be held at the Banff Springs Hotel, Alberta. The practitioners' and scientific portions of the meeting will begin on the evening of Saturday February 22, 2003 with the

\section{Abbott Laboratories Ltd. \\ Axcan Pharma Inc.}


McKenna Memorial Lecture and conclude on the evening of Tuesday February 25, 2003. Des Leddin is Chair of the Implementation Committee for CDDW 2003. Please forward your comments and suggestions to Des for his consideration. A new initiative planned for next year is the first annual Educational Excellence Award, which will honour the achievements of one of our members with regard to advancing teaching and educational expertise in our subspecialty.
As president of the CAG, I will travel to the World Congress of Gastroenterology in Bangkok, Thailand to cast our ballot on Wednesday February 27, 2002 to decide where the next meeting will be held in the autumn of 2005. As you know, the Canadian Bid Federation, led by Richard Fedorak, has been instrumental in putting Montreal, Quebec, and Canada in a most favourable position. I will report the outcome of the bid in the April CAG News Page. 


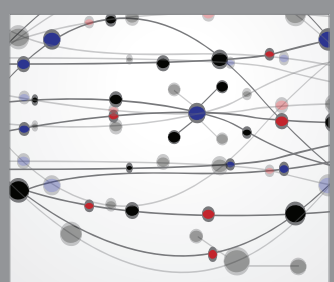

The Scientific World Journal
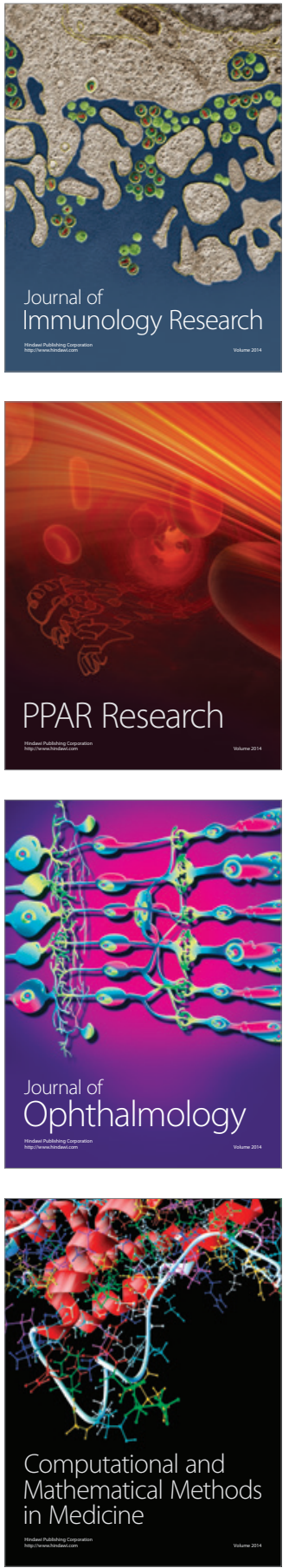

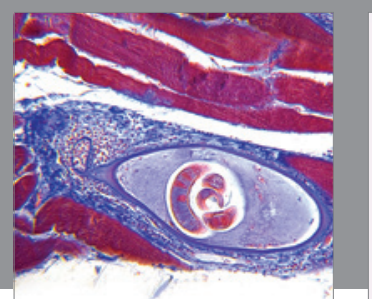

Gastroenterology Research and Practice

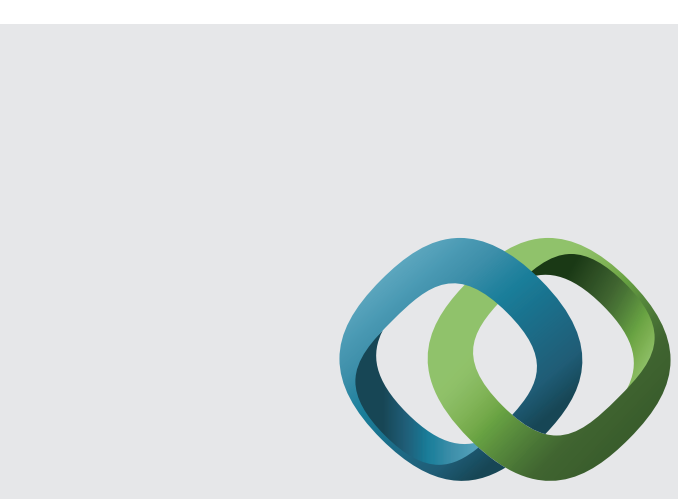

\section{Hindawi}

Submit your manuscripts at

http://www.hindawi.com
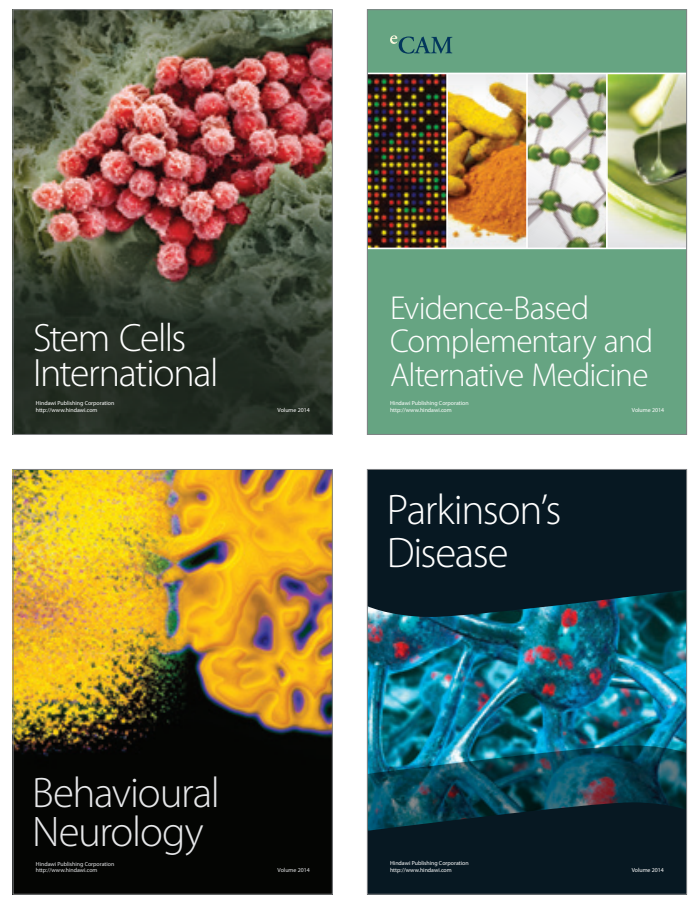
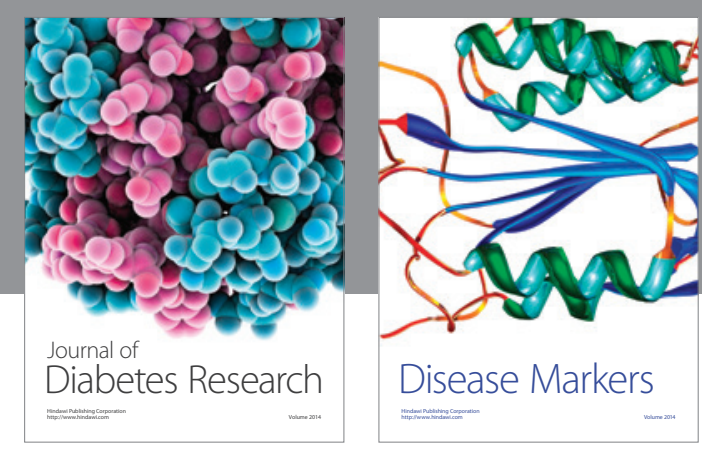

Disease Markers
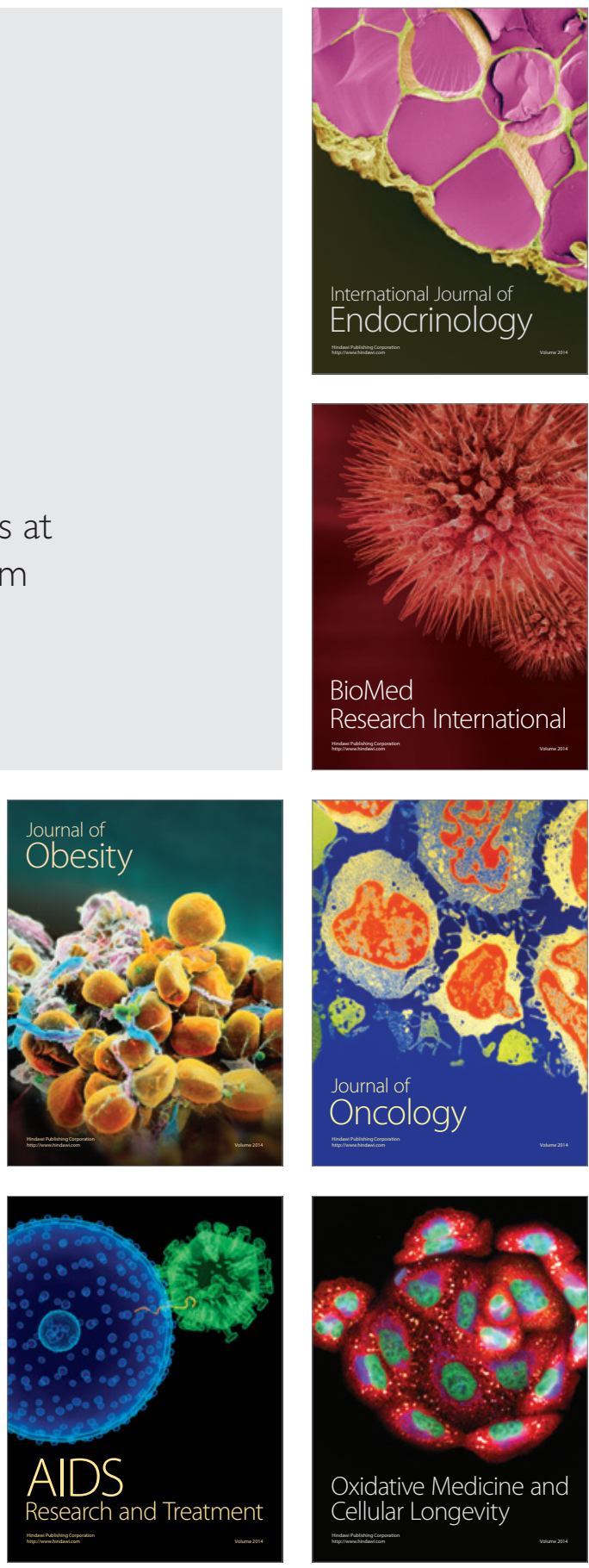